\title{
Effect of Artificial Aging and Cooling Rate on Microstructure and Mechanical Properties of AA6082
}

\author{
Mehmet Şahbaz $^{1^{*}}$ \\ ${ }^{1 * K a r a m a n o g ̆ l u ~ M e h m e t b e y ~ U n i v e r s i t y, ~ F a c u l t y ~ o f ~ E n g i n e e r i n g, ~ D e p a r t m e n t ~ o f ~ M e c h a n i c a l ~ E n g i n e e r i n g, ~ K a r a m a n, ~ T u r k e y, ~(O R C I D: ~ 0000-0001-6379-8345), ~}$ \\ mehmetsahbaz@kmu.edu.tr
}

(1st International Conference on Applied Engineering and Natural Sciences ICAENS 2021, November 1-3, 2021)

(DOI: 10.31590/ejosat.998077)

ATIF/REFERENCE: Şahbaz, M. (2021). Effect of Artificial Aging and Cooling Rate on Microstructure and Mechanical Properties of AA6082. European Journal of Science and Technology, (28), 300-305.

\begin{abstract}
In this study, the change of microstructure and mechanical properties of 6082 aluminium alloy as a result of heat treatment was examined. Materials selected as heat treatment are first annealed at $450{ }^{\circ} \mathrm{C}$ for 2 hours, so the residual stresses are eliminated and the grain structure is homogenized. Afterwards, the annealed samples were cooled in 3 different environments (by waiting in the oven, by air in the room environment, and in water in the room environment) and the effect of these environments was studied. In addition, by applying artificial aging specimens were prepared under four different conditions, and mechanical properties were examined by performing hardness and compression tests for these four different conditions, and microstructural properties were examined with the help of an optical microscope. As a result, the effects of post-annealing cooling rate and artificial aging on the material were determined and the connection between microstructural changes and mechanical properties was discussed in the context of the results obtained. Depending on the cooling rate and artificial aging, different grain structures and secondary phase precipitates were determined for each case in the microstructure examinations. In connection with this situation, the increase in the mechanical properties was observed with the increase of the cooling rate, and the highest increase was seen in the aged material.
\end{abstract}

Keywords: Artificial aging, Heat treatment, Compression test, Hardness test, Optical microscope.

\section{Yapay Yaşlandırma ve Soğutma Hızının AA6082'nin Mikroyapı ve Mekanik Özelliklerine Etkisi}

\begin{abstract}
$\ddot{O} \mathbf{z}$
Bu çalıșmada 6082 alüminyum alaşımının ısıl işlem sonucunda mikro yapı ve mekanik özelliklerinin değișimi incelenmiștir. Issıl ișlem olarak seçilen malzemeler önce $450{ }^{\circ} \mathrm{C}^{\prime} \mathrm{de} 2$ saat tavland1, böylece artık gerilmeler giderildi ve tane yapısı homojen hale getirildi. Daha sonra tavlanan numuneler 3 farklı ortamda (firında bekleterek, oda ortamında hava ile ve oda ortamında su ile) soğutuldu ve bu ortamların etkisi incelendi. Ayrıca suni yaşlandırma da uygulanarak numuneler dört farklı koşulda hazırlanmış ve bu dört farklı koşul için sertlik ve basma testleri yapılarak mekanik özellikler incelenmiş ve optik mikroskop yardımıyla mikroyapısal özellikler incelenmiştir. Sonuç olarak, tavlama sonrası soğuma hızının ve yapay yaşlandırmanın malzeme üzerindeki etkileri belirlenmiş ve elde edilen sonuçlar bağlamında mikroyapısal değişimler ile mekanik özellikler arasındaki bağlantılar tartışılmıştır. Soğuma hızına ve suni yaşlandırmaya bağlı olarak her bir durum için farklı tane yapıları ve ikincil faz çökeltileri gözlemlenmiştir. Soğutma hızının artmasıyla mekanik özelliklerde artış gözlemlenmiş ve en yüksek artış da yapay yaşlandırılan malzemede görülmüşsür.
\end{abstract}

Anahtar Kelimeler: Yapay yaşlandırma, Isıl işlem, Basma testi, Sertlik testi, Optik mikroskop.

* Corresponding Author: mehmetsahbaz@,kmu.edu.tr 


\section{Introduction}

Aluminium alloys are the second most used metal in the world after iron and steel derivatives. It is possible to improve the casting or mechanical properties of aluminium that are not at the desired level in pure form, by alloying with the addition of metals such as copper, magnesium, silicon, and zinc. In addition, the strength of this material is increased by methods such as heat treatments, forging, rolling, and severe plastic deformation. Thus, a material with high strength relative to its weight is obtained, which is very important in the automotive and aviation industries. Moreover, aluminium and its alloys are a popular material that is increasingly used both in the industrial field and in our daily life due to its low density, high strength, easy workability, high thermal and electrical conductivity (Altenpohl et al., 1998; Özbeyaz et al., 2019; Şahbaz, Kentli, et al., 2020; Türkmen et al., 2015).

Due to the decreasing energy resources on a global basis in recent years, the use of automotive aluminium for fuel-saving has increased from $10 \%$ to $80 \%$. According to the alloy materials of aluminium, some can be aged, while others are not suitable for this process. Some studies are carried out to determine the required temperature and time to ensure maximum efficiency from the aging process, and the most appropriate parameters are tried to be determined.

The 6000 series alloys (Al-Mg-Si alloys), which are among the age hardenable aluminium alloys, are the most commonly used in the extrusion industry and constitute more than $80 \%$ of the aluminium products produced by extrusion. These alloys are known for their good extrudability, high corrosion resistance, good weldability, the clean surface after hot forming, and low cost of processes applied to achieve moderate strength (Başer, 2015). AA 6082 aluminium alloy, which is one of the aging aluminium alloys, is one of the aluminium alloys that has been increasingly used in recent years. These alloys have high formability, plating properties, and mechanical values with heat treatment are significantly good (Başer, 2015; Demirpolat et al., 2021; Türkmen et al., 2015).

In this study, the change in the mechanical properties of AA 6082 alloy depending on the cooling rate after heat treatment will be examined. This work is especially important for the preparation of the material before the extrusion processes under the recrystallization temperature. The rate of heat treatment and cooling rate is decisive in the application of the extrusion process and in the properties that the material will gain afterwards. Especially in Severe Plastic Deformation (SPD) processes, it is very important to prepare the material before the process, to apply the process, and to reach the desired level of microstructural and mechanical properties afterwards (Öğ̈̈t, Kaya, Kentli, \& Uçar, 2021; Öğüt, Kaya, Kentli, Özbeyaz, et al., 2021; Şahbaz, Kaya, et al., 2020).

In addition, the artificial aging process will be applied to the annealed material and the change in material properties will be examined. The effects of applied heat treatments on the material microstructure will be examined and a connection will be made with the change in mechanical properties. Hardness and rarely used compression tests will be used in the determination of mechanical properties, and an optical microscope and image analysis will be used in microstructure examination.

\section{Material and Method}

For this study, AA6082, one of the most widely used aluminium alloys, was chosen. Although this alloy mostly contains Silicon ( $\mathrm{Si})$ and Magnesium $(\mathrm{Mg})$ elements, its chemical composition is given in Table 1 below. The most important factor in the examination of this alloy is that 6000 series aluminium alloys are highly preferred in the production of products by extrusion and they are age hardenable alloys (Türkmen et al., 2015).

\subsection{Heat Treatments}

Cylindrical specimens with a diameter of $20 \mathrm{~mm}$ were cut into pieces of $40 \mathrm{~mm}$ length for compression testing and $20 \mathrm{~mm}$ pieces for hardness testing and microstructure analysis. These samples were annealed in the heat treatment furnace at 450 degrees for 2 hours. Afterwards, 1 group was left to cool in the oven, 1 group was cooled in air, 2 groups were cooled in water. 1 group of watercooled was artificially aged at $195^{\circ} \mathrm{C}$ for 8 hours.

If the cooling rates of the samples are calculated according to the environments in which they are cooled, approximately the following values are obtained: $100{ }^{\circ} \mathrm{C} / \mathrm{sec}$ for the water-cooled sample, $1{ }^{\circ} \mathrm{C} / \mathrm{sec}$ for air cooling, and $0.01{ }^{\circ} \mathrm{C} / \mathrm{sec}$ for cooling in the furnace. Accordingly, these cooling environments can be named as fast, moderate, and slow cooling.

Table 1. Chemical composition of the AA6082 (\%)

\begin{tabular}{cccccccccc}
\hline $\begin{array}{c}\text { Aluminium } \\
\mathbf{A l}\end{array}$ & $\begin{array}{c}\text { Chrome } \\
\mathbf{C r}\end{array}$ & $\begin{array}{c}\text { Copper } \\
\mathbf{C u}\end{array}$ & $\begin{array}{c}\text { Iron } \\
\mathbf{F e}\end{array}$ & $\begin{array}{c}\text { Magnesium } \\
\mathbf{M g}\end{array}$ & $\begin{array}{c}\text { Manganese } \\
\mathbf{M n}\end{array}$ & $\begin{array}{c}\text { Silicon } \\
\mathbf{S i}\end{array}$ & $\begin{array}{c}\text { Titanium } \\
\mathbf{T i}\end{array}$ & $\begin{array}{c}\text { Zinc } \\
\mathbf{Z n}\end{array}$ & Other \\
\hline $95.2-98.3$ & 0.25 & 0.10 & 0.50 & $0.60-1.2$ & $0.40-1.0$ & $0.70-1.3$ & 0.10 & 0.20 & 0.50 \\
\hline
\end{tabular}

\subsection{Mechanical Tests}

The test specimens were prepared in accordance with TSE 206 compression test standards, with dimensions of $20 \mathrm{~mm}$ diameter (D0) and $40 \mathrm{~mm}$ length (L0), and L0/D0=2 according to ASTM E9 - 89 (short sample) dimensions (Fig.1). These samples were subjected to the compression test with a strain rate of 0.05 $\mathrm{mm} / \mathrm{mm} \cdot \mathrm{d}$ according to the standard $(2 \mathrm{~mm} / \mathrm{d})$ in Shimadzu brand AGS $100 \mathrm{kN}$ series electromechanical tensile-compression test device. All specimens were pressed up to $10 \mathrm{~mm}$ (until $25 \%$ strain change) and Stress-Strain and Force - Displacement curves were obtained. In addition, necessary mechanical properties such as yield strength, maximum compression strength, and toughness were obtained from these curves.

The other samples, which were subjected to the same heat treatment, were first sandpapered gradually for the hardness test and then polished, thus the surface was prepared in order to obtain the most accurate result in the hardness test. 


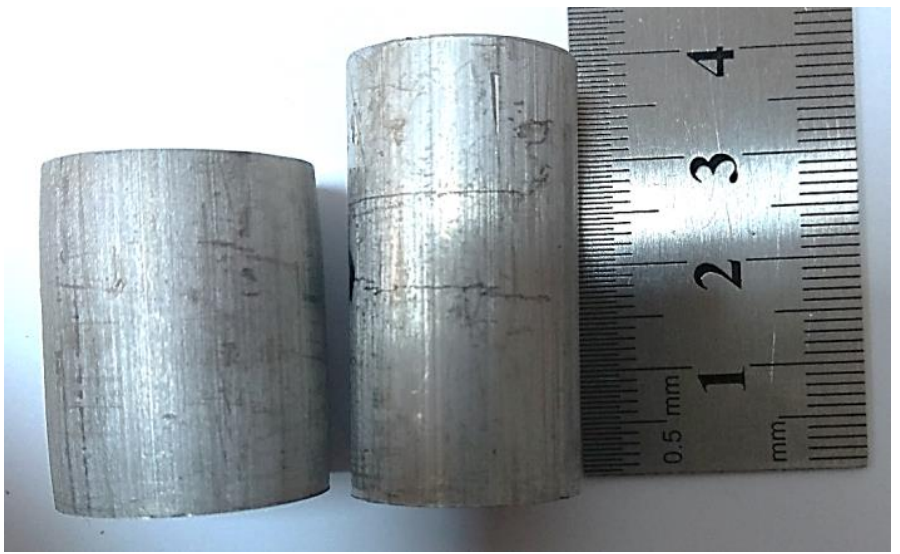

Figure 1. Specimens prepared fro m AA6082 before compression test (right), after the test (left)

Hardness tests were performed using the Digirock-Rbov-M brand test device according to the Brinell method. In the hardness measurements, the preload was determined as $10 \mathrm{kgf}$, the total load was $62.5 \mathrm{kgf}$ and the dwell time was 6 seconds. In addition, a $2.5 \mathrm{~mm}$ diamond ball-tipped test device tip was used. At least 5 traces were taken for each measurement and the average was used as the final result.

\subsection{Microstructural Analysis}

Specimens prepared in four different thermal conditions for microstructure examination were first subjected to sanding with water cooling. The grinding process was performed at $300 \mathrm{rpm}$ for 3 minutes, starting from 320 mesh with 800, 1200, and 2500 mesh SiC-containing sandpapers. Afterwards, polishing was done with 6 microns and 1-micron diamond solutions at the same speed and time. As a result of the polishing process, the sample surfaces have reached the level called mirror-like (Fig.2). For the etching process, the specimens were kept in Keller reagent $(2 \mathrm{ml} \mathrm{HF}+3 \mathrm{ml}$ $\mathrm{HCl}+5 \mathrm{ml} \mathrm{HNO} 3+190 \mathrm{ml}$ Water) for 1 minute, then Weck's reagent was dripped and left for 30 seconds, rinsed with water, and dried with hot air.

Microstructure examinations were made using a Nikon Eclipse MA100 inverted optical microscope. Images of different sizes were taken from different parts of each sample and attention was paid to ensure that these images were representative of the whole microstructure.

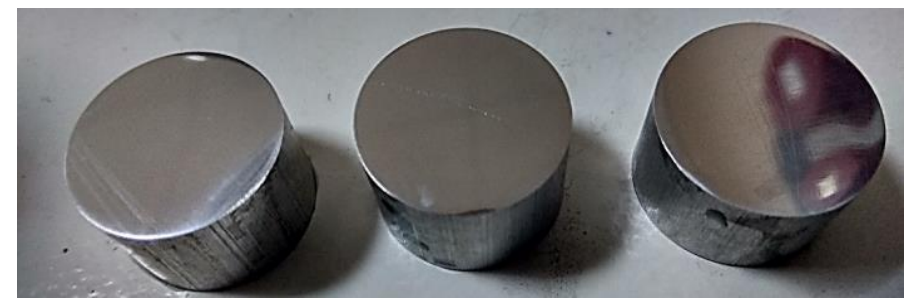

Figure 2. The mirror-like surface of the polished specimens

\section{Results and Discussion}

As a result of the compression tests of the specimens prepared under different thermal conditions, the results given in the graphs and table below were obtained. In the tests conducted for four different situations, the results showed higher resistance than the others, which were cooled rapidly in water in the room environment (about $18{ }^{\circ} \mathrm{C}$ ), as expected. Afterwards, the sample was cooled by natural convection air $\left(20{ }^{\circ} \mathrm{C}\right)$ in the room environment, followed by the one cooled in the furnace. The e-ISSN: 2148-2683 sample, on which artificial aging was applied as additional heat treatment, gained more mechanical properties in all of them, this is clearly seen in the graphic and table values.

As a result of the study, the yield strength, compressive strength, and toughness values of AA6082 Al alloy increased with the increase of the cooling rate. This situation emerged as a result of the decrease of grain size and the formation of smaller precipitates with the increase in cooling rate, or the presence of more free $\mathrm{Mg}$ and $\mathrm{Si}$ atoms in the solid solution. These results show similarity with the literature studies (Akyuz \& Şenaysoy, 2014; Gündüz \& Kaçar, 2008).

(a)

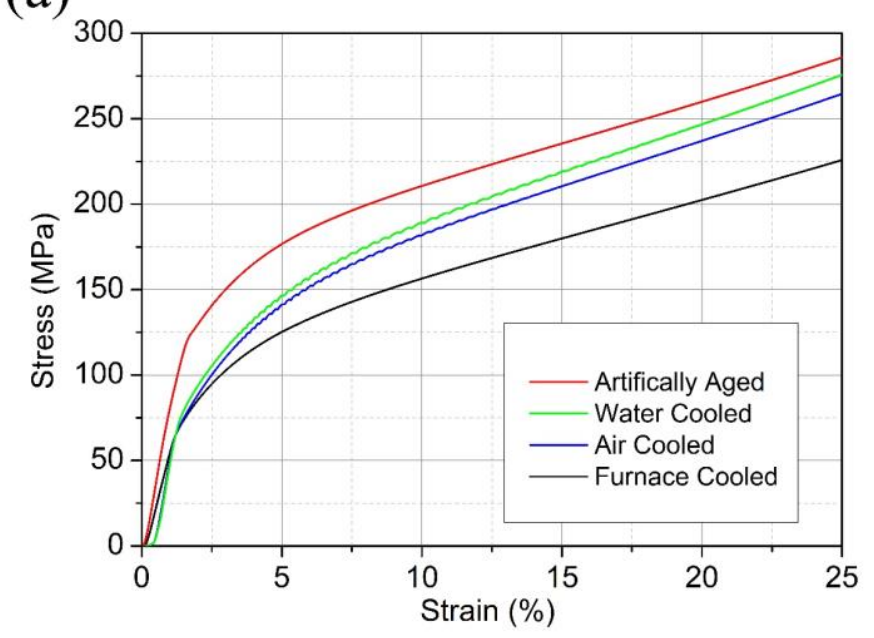

(b)

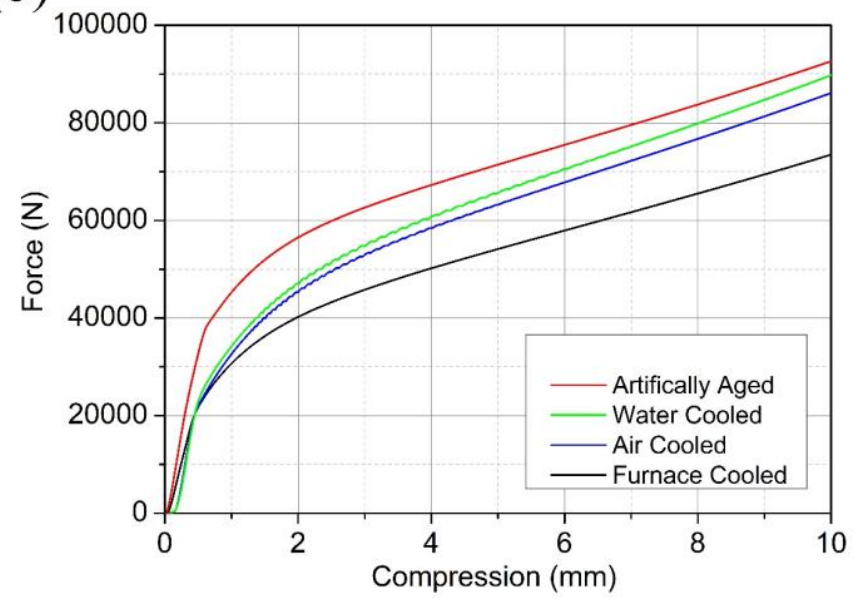

Figure 3. AA6082 compression test results a) Stress- Strain graph, b) Force - Compression graph

As seen in Figure 3, the strength values of the materials increase as the cooling rate increases after annealing. In this case, the lowest strength was observed in the material cooled in the furnace, while the highest strength was observed in the material cooled in water. In addition, more compression strength was measured in the artificially aged specimen upon cooling in water.

In this study, since $25 \%$ of the initial length of the specimens was compressed, the maximum compression strength was measured for this level. In Table 2, the strength, toughness and hardness values calculated at the end of the compression test are given. 
Table 2. Measured mechanical properties of AA6082

\begin{tabular}{l|cccc}
\hline & $\begin{array}{c}\text { Yield } \\
\text { Strength } \\
\text { (MPa) }\end{array}$ & $\begin{array}{c}\text { Maximum } \\
\text { Compression } \\
\text { Strength } \\
\text { (MPa) }\end{array}$ & $\begin{array}{c}\text { Toughness } \\
\text { Energy }\end{array}$ & Hardness \\
\hline $\begin{array}{l}\text { The cooled in } \\
\text { the oven }\end{array}$ & 73,63 & 233,93 & 516,37 & $\mathbf{( H B )}$ \\
$\begin{array}{l}\text { The cooled } \\
\text { in the air } \\
\begin{array}{l}\text { The cooled in } \\
\text { the water } \\
\text { Artificially }\end{array}\end{array}$ & 73,45 & 274,13 & 596,63 & 37,2 \\
Aged & 115,96 & 285,71 & 620,35 & 39,1 \\
\hline
\end{tabular}

Optical microscope images of the microstructures of the tested specimens for all conditions are given in Table 3 at 20X and 50X magnifications.
If the microstructure pictures are examined separately for each case, secondary elements $(\mathrm{Mg}-\mathrm{Si})$ due to slow cooling in the material cooled in the furnace recovered and formed the beta phase, which is defined as the Chinese script in the literature (Yuan et al., 2002; Zengin et al., 2019) (Table 3a). In the air cooled material case, it is seen that since the secondary phases could not find the time to fully recover, they precipitated between the grains in the form of small particles (Table 3d).

On the other hand, in the water cooled material case, large beta phases could not form due to sudden cooling, and small-sized secondary phases were concentrated in the pores resulting from the dendritic structure formed in the main material (Table $3 \mathrm{f}$ ). As a result of the artificial aging process, it was obtained as desired, beta phases (those that appear bright in the grains of the main material) were formed smaller than alpha phases and were trapped inside the alpha phases (Özer, 2003) (Table 3h).

In addition, when the general table is examined, a decrease in grain size is observed depending on the cooling rate, and this is the factor that increases the strength of the material according to the Hall-Petch relation (Şahbaz et al., 2019).

Table 3. Optical microscope images of the microstructures

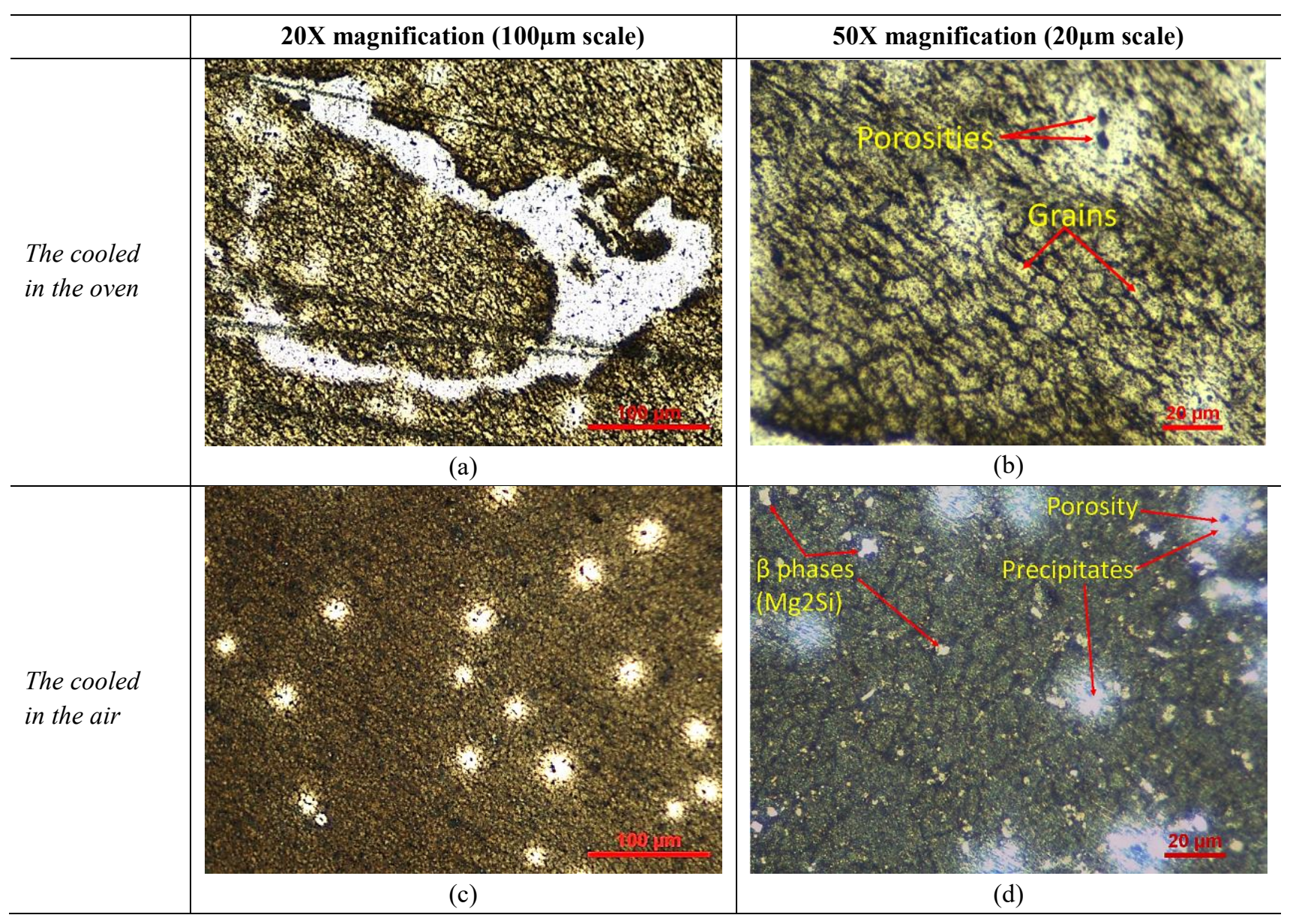




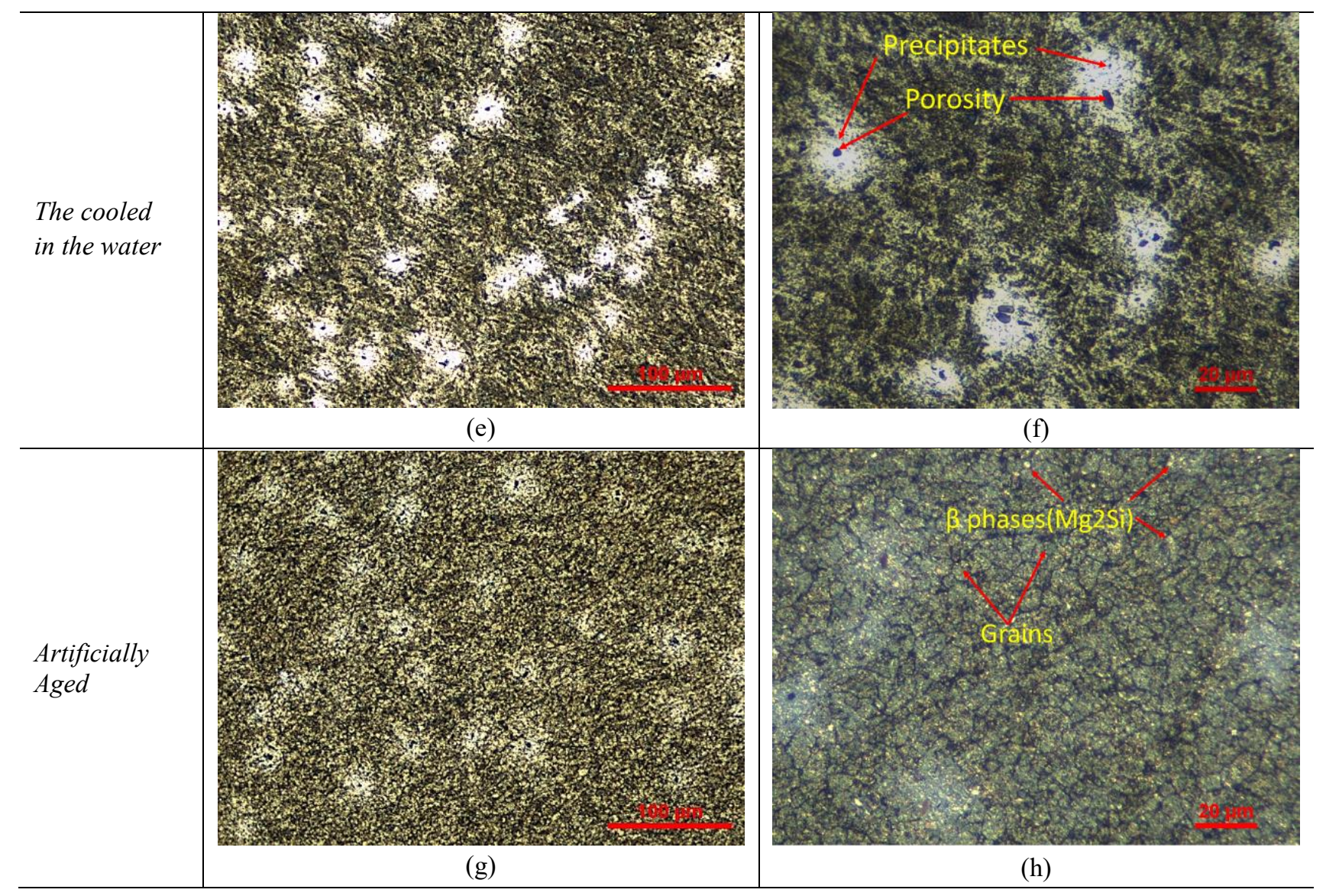

\section{Discussion}

1. AA6082 alloy was found to have the lowest compression strength, yield strength, and hardness with the cooling in the furnace after annealing at $450{ }^{\circ} \mathrm{C}$ for 2 hours. This is an indication that the material grain size grows and secondary phase precipitates such as $\mathrm{Mg} 2 \mathrm{Si}$ become coarser as a result of slow cooling.

2. With the increase in the cooling rate of 6082 aluminium alloy, which was annealed at $450{ }^{\circ} \mathrm{C}$ for 2 hours and cooled in different environments, a decrease was observed in the grain size and a decrease in the dimensions of the precipitate. However, the yield strength, compression strength, and hardness of the samples increased with the increase in cooling rate.

3. In these experimental studies, it was observed that the sample cooled in water environment gained the highest strength and hardness compared to the samples cooled in other environments. While these values increased with the aging process applied to this sample, significant improvements were observed in the microstructure of the material.

4. Annealing is a method that is widely applied to the material, especially before the Severe Plastic Deformation (SPD) applications. In SPD applications, it is desirable that the secondary phases precipitate at the grain boundary as well as reducing the grain size in order to increase the strength (Günay Bulutsuz \& Chrominski, 2021). The findings obtained from this study showed that: since the secondary phase precipitations are in the form of small particles in air-cooled samples, the desired situation is achieved with a few passes.
5. Since the secondary phase dimensions are huge in the sample cooled in the furnace, breaking them to the desired dimensions requires a high number of passes in the SPD process.

6. In the sample cooled in water, since the secondary phase dimensions are very small, although it precipitates at the grain boundary, it cannot provide the desired effect, namely the increase in the dislocation density, at the desired level. In addition, increasing strength and hardness values will complicate the SPD process.

7. In the aging sample, the hardness and strength have increased, in this case, the application of SPD has become difficult, and high strength and a mould to withstand it are required for the process. If these obstacles are overcome, the beta phases trapped in the alpha phase precipitate at the grain boundaries, and the desired result can be obtained in the aged sample. Otherwise, the application of the aging process after the SPD process may cause an improvement in the microstructure of the material and increase its mechanical properties.

\section{Conclusions}

In this study, AA6082 aluminium alloy was annealed at 450 ${ }^{\circ} \mathrm{C}$ for 2 hours, cooled at different cooling rates $(100 \mathrm{C} / \mathrm{sec}, 1$ $\mathrm{C} / \mathrm{sec}$, and $0,01 \mathrm{C} / \mathrm{sec}$ ), and then artificially aging process was applied.

Due to the slow cooling rate in the (slow) cooling sample in the furnace, the beta phases found time to recover and precipitate. While this situation is partially visible on the sample that cools in the air (moderately), it is not possible to see this situation in the sample that cools down (fast) in water. Due to the high cooling rate in the sample cooled in water, secondary phases such as 
$\mathrm{Mg} 2 \mathrm{Si}$ could not recover and precipitated around the pores. In addition, the grains of the parent material remained small, could not become circular, and formed a dendritic structure. This increased the compressive strength and hardness values as it decreased the intergranular flexibility and increased the dislocation density.

In order to see the effect of artificial aging, when the microstructure of the sample aged at $195{ }^{\circ} \mathrm{C}$ for 8 hours is examined, it is seen that the pores decrease and the grain size decreases. In addition, it was observed that the secondary phases decreased in size and took place in the main material grains. This situation has increased the compressive strength and hardness of the material by positively affecting the mechanical properties of the material.

\section{References}

Akyuz, B., \& Şenaysoy, S. (2014). Alüminyum Alaşımlarında Yaşlandırma İşleminin Mekanik Özellikler ve İşlenebilirlik Üzerindeki Etkisi Effect of Aging on Mechanical Properties and Machining on Aluminum Alloys. Bilecik Şeyh Edebali Üniversitesi Fen Bilimleri Dergisi, 2330(1), 1-9. http://edergi.bilecik.edu.tr/index.php/fbd

Altenpohl, D., Das, S. K., \& Kaufman, J. (1998). Aluminium Technology, Applications and Environment: A Profile of a Modern Metal Aluminum from Within. In Aluminum: Technology, Applications, and Environment - TMS. Aluminum Association.

Başer, T. A. (2015). Effect of aging parameters on the mechanical properties of naturally aged Al-Mg-Si alloy. Materialwissenschaft Und Werkstofftechnik, 46(8), 829-834. https://doi.org/10.1002/mawe.201500342

Demirpolat, H., Akd1, S., \& Alkan, B. (2021). The Effect of Homogenization and Chemical Compositions of 6005 and 6082 Aluminium Alloys on The Cold Forming Process. European Journal of Science and Technology, 28(28), 16-20. https://doi.org/10.31590/ejosat.973063

Günay Bulutsuz, A., \& Chrominski, W. (2021). Incremental Severe Plastic Deformation Effect on Mechanical and Microstructural Characteristics of AA6063. Transactions of the Indian Institute of Metals, 74(1), 69-77. https://doi.org/10.1007/s12666-020-02122-4

Gündüz, S., \& Kaçar, R. (2008). Strengthening of 6063 aluminium alloy by strain ageing. Kovove Materialy, 46(6), $345-350$.

https://www.researchgate.net/publication/285590175

Öğüt, S., Kaya, H., Kentli, A., Özbeyaz, K., \& Şahbaz, M. (2021). Investigation of Strain Inhomogeneity in Hexa-ECAP Processed AA7075. Arch. Metall. Mater, 66, 431-436. https://doi.org/10.24425/amm.2021.135875

Öğüt, S., Kaya, H., Kentli, A., \& Uçar, M. (2021). Applying Hybrid Equal Channel Angular Pressing (HECAP) to pure copper using optimized Exp.-ECAP die. PREPRINT. https://doi.org/10.21203/RS.3.RS-371053/V1

Özbeyaz, K., Kaya, H., Kentli, A., Şahbaz, M., \& Öğüt, S. (2019). Mechanical properties and electrical conductivity performance of ECAP processed AA2024 alloy. Indian Journal of Chemical Technology, 26(26), 266-269.

Özer, H. H. (2003). 7075 alüminyum alaşımında retrogresyon ve yeniden yaşlandırma ısıl işlemi sonucu mekanik özelliklerin incelenmesi. http://dspace.yildiz.edu.tr/xmlui/handle/1/9932

Şahbaz, M., Kaya, H., \& Kentli, A. (2020). A new severe plastic deformation method: thin-walled open channel angular pressing (TWO-CAP). International Journal of Advanced Manufacturing Technology, 106(3-4), 1487-1496. https://doi.org/10.1007/s00170-019-04748-1

Şahbaz, M., Kaya, H., Kentli, A., Uçar, M., Öğüt, S., \& Özbeyaz, K. (2019). Experimental Comparison of Al5083 Alloy Subjected to Annealing and Equal-Channel Angular Pressing. International Journal of Computational and Experimental Science and Engineering, 5(1), 52-55. https://doi.org/10.22399/IJCESEN.394542

Şahbaz, M., Kentli, A., \& Kaya, H. (2020). Performance of Novel TWO-CAP (Thin-Walled Open Channel Angular Pressing) Method on AA5083. Metals and Materials International. https://doi.org/10.1007/s12540-019-00594-8

Türkmen, M., Akdemir, O., Taşpınar, Y., Yıldız, M., \& Gündüz, S. (2015). The Effect of Cooling Rate on Microstructure and Mechanical Properties of Al-Mg-Si (6063) Alloy. Pamukkale University Journal of Engineering Sciences, 21(1), 11-14. https://doi.org/10.5505/pajes.2014.30075

Yuan, G. Y., Liu, Z. L., Wang, Q. D., \& Ding, W. J. (2002). Microstructure refinement of $\mathrm{Mg}-\mathrm{Al}-\mathrm{Zn}-\mathrm{Si}$ alloys. Materials Letters, 56(1-2), 53-58. https://doi.org/10.1016/S0167$577 \mathrm{X}(02) 00417-2$

Zengin, H., Turen, Y., Ahlatçı, H., Sun, Y., \& Karaoğlanlı, A. C. (2019). Influence of $\mathrm{Sn}$ addition on microstructure and corrosion resistance of AS21 magnesium alloy. Transactions of Nonferrous Metals Society of China (English Edition), 29(7), 1413-1423. https://doi.org/10.1016/S10036326(19)65048-X 